\title{
"Nie ze mną trzeba być, lecz we mnie..." Problem samotności, indywidualizmu i wspólnoty w twórczości Adama Mickiewicza
}

DOI: http://dx.doi.org/10.12775/RF.2014.033

W książce Izajasza Berlina Korzenie romantyzmu, będącej zapisem wykładów wygłoszonych przez tego brytyjskiego filozofa w roku 1965, pomieszczono niezwykle liczną kolekcję definicji romantyzmu. Sam Berlin zdaje się akceptować je wszystkie, jednocześnie do większości z nich zgłaszając różne zastrzeżenia. Filozof nie podaje własnej definicji, ograniczając się do wymienienia cech i najważniejszych symptomów tej epoki. Berlin pisze między innymi:

[Romantyzm] to nostalgia, to zaduma, to upajające sny, to słodka melancholia i gorzka melancholia, to samotność, to cierpienia związane z wygnaniem, to poczucie wyobcowania, to błądzenie po odległych krainach, zwłaszcza na Wschodzie i w odległym czasie, zwłaszcza w średniowieczu. Ale także dająca poczucie szczęścia współpraca we wspólnym twórczym wysiłku, ale także świadomość, że stanowi się cząstkę Kościoła, cząstkę jakiejś klasy, partii, tradycji, wielkiej i wszechogarniającej symetrycznej hierarchii, to rycerze i czeladź, to wierni Kościoła, to organiczne więzi społeczne, to mistyczna jedność, jedna wiara, jeden kraj, jedna krew $(\ldots)^{1}$.

Badacz romantyzmu próbujący wyodrębnić nurty myślowe, które dominowałyby w tej epoce, jest bezradny wobec gąszczu idei i koncepcji, które ścierały się w dziełach poszczególnych twórców. Często nie-

1 I. Berlin, Korzenie romantyzmu. Wykłady mellonowskie w zakresie sztuk pięknych wygłoszone w Narodowej Galerii Sztuki w Waszyngtonie, red. H. Hardy, przeł. A. Bartkowicz, Poznań 2004, s. 43-44. 
możliwe okazuje się wyznaczenie kierunku, w którym skierowane byłyby koncepcje danej grupy twórców, nie można też powiedzieć, że dany pogląd był w tej epoce poglądem dominującym - zawsze można znaleźć dowody przeczące takiej tezie. Takie problemy wiążą się też z badaniem poglądów nawet pojedynczych twórców i myślicieli, którzy najwyraźniej nie uznawali za konieczne obstawania przy określonych poglądach zbyt długo.

Romantyzm to także epoka, w której trudno wyznaczyć kilka problemów dominujących - problemów, wokół których koncentrowała się myśl romantyczna, było bardzo dużo. Do najważniejszych należała z pewnością kwestia stosunku jednostki do grupy społecznej, prezentowana $\mathrm{w}$ rozmaitych wariantach i odmianach. W tej - jak się czasem twierdzi - mało filozoficznej epoce, główny ciężar przenoszenia i rozprzestrzeniania idei, wzięła na siebie literatura. Roi się w niej od postaci, których relacje z innymi ludźmi, z danymi grupami ludzi, zdają się odbiegać od normy. Ale co mogło uchodzić za normę, jeśli na równych prawach egzystowały obok siebie postawy charakterystyczne dla wymienionych przez Berlina postaci byronowskich, a także bohaterowie poświęcający się dla dobra ogółu; jednostki uciekające od społeczeństwa w samotność i jednostki spychane przez społeczeństwo na margines, poza nawias; jednostki dominujące nad innymi, przewodzące masom i takie postaci, którym bardzo blisko do znanego z wcześniejszych epok Everymana czy Quidama? Wyobraźnia twórców romantycznych kazała im wplątywać swoich bohaterów w bardzo złożone stosunki społeczne, ale także wypychać ich poza obręb społeczeństwa. Liczni byli tacy pisarze, którzy nie potrafili jednoznacznie określić się po stronie indywidualizmu lub „kolektywizmu”, a w kolejnych swoich dziełach dawali wyraz swym - często wzajemnie sprzecznym - poglądom na ten temat.

Źródeł rozbieżnych poglądów romantyków na zagadnienie stosunku jednostki do społeczeństwa szukano na różne sposoby, osadzając źródła myśli romantycznej $\mathrm{w}$ dorobku intelektualnym wcześniejszych epok, w przemianach społecznych czy wydarzeniach historycznych. Bezsprzecznie do najważniejszych pobudek intelektualnych należy zaliczyć pisma Jana Jakuba Rousseau, natomiast wydaje się, że nie mniej ważne przemiany $\mathrm{w}$ mentalności przyniosły wielkie wydarzenia historyczne u progu romantyzmu - wielka rewolucja francuska, która pokazała siłę, znaczenie masy, tłumu, narodu, a także następująca po niej epoka napoleońska, z której wyniesiono lekcję o możliwościach, jakie stoją przed jednostką ludzką ${ }^{2}$. Trudno się zatem dziwić, że w jednej epoce można znaleźć tak wiele realizacji tematu stosunku jednostki do społeczeństwa, rozdźwięku i napięcia między indywidualizmem a kolektywizmem, ucieczką w samotność i przynależnością do określonej

2 Zob. M. Janion, M. Żmigrodzka, Romantyzm i historia, Warszawa 1978, s. 185. 
grupy społecznej. Taką rozmaitość można odnaleźć nawet w twórczości pojedynczych pisarzy. Na gruncie polskim szczególnie ciekawą postacią może okazać się Adam Mickiewicz, który na przestrzeni kilkudziesięciu lat wracał do wątku samotności i wspólnotowości bardzo często i podejmował go na rozmaite sposoby.

Publikacja Ballad i romansów Mickiewicza w roku 1822 często uznawana jest za początkową datę polskiego romantyzmu. Mickiewicz jest jednak autorem kilku innych tekstów uznanych za sztandarowe, wśród nich Ody do młodości (1820). W wierszu tym, obok pochwały młodości i związanej z nią energii, a także przygany dla starości, która powinna ustąpić pola młodemu pokoleniu, znajdziemy negatywnie nacechowany obraz człowieka, który jest „Sam sobie sterem, żeglarzem, okrętem”3. Człowiek taki opisywany jest jako drobne żyjątko unoszące się wśród odmętów, które wreszcie ginie zapomniane przez innych ludzi. Takiego losu pozwala uniknąć towarzystwo przyjaciól, a poświęcenie na rzecz innych konotowane jest tu pozytywnie: „W szczęściu wszystkiego są wszystkich cele; / Jednością silni, rozumni szalem, / Razem młodzi przyjaciele!... / I ten szczęśliwy, kto padł wśród zawodu, / Jeżeli poległym ciałem /Dał innym szczebel do sławy grodu" ${ }^{\prime 4}$.

Zjednoczone wysiłki grupy ludzi, skoncentrowane wokół wspólnego celu, dają nadludzką moc - umożliwiają pchnięcie „bryły z posad świata". Piszący te słowa Adam Mickiewicz obracał się w towarzystwie dobrych przyjaciół, ludzi, z którymi wiązały go podobne ideały i zbliżone poglądy (niektórym z nich dwa lata później miał zadedykować swój debiutancki tom poezji, który zapewnił mu poczesne miejsce $\mathrm{w}$ gronie ówczesnych poetów). To sielankowe braterstwo filomackie nie trwało jednak długo. Zaledwie rok później młody Mickiewicz, przepełniony goryczą wywołaną sporami w wileńskich towarzystwach studenckich, pełen poczucia niezrozumienia ze strony dotychczasowych towarzyszy, napisał wiersz Żeglarz. Po raz kolejny stosuje w nim metaforykę marynistyczną i zaznacza swój - żeglarza - dystans do przyjaciół, do „braci”, którzy pozostali na brzegu, „,na nadbrzeżnej skale”, i nie podążają razem z nim: „I razem ze mną pod strzałami gromu, / Co czuje, inni uczuć chcieliby daremnie! / Sąd nasz, prócz Boga, nie dany nikomu. / Chcąc mnie sądzić, nie ze mną trzeba być, lecz we mnie. / - Ja płynę dalej, wy idźcie do domu" ${ }^{\prime \prime}$.

To pierwszy w dorobku Mickiewicza tak indywidualistyczny ustęp, pierwsza tak silna i wyrazista deklaracja własnej odmienności, pierwsza literacka próba pokazania, że poeta nie potrzebuje grona towarzyszy, nie potrzebuje wspólnoty do realizacji swoich celów, równie dobrze może

\footnotetext{
3 A. Mickiewicz, Wiersze, Warszawa 1986, s. 28.

4 Ibidem.

Ibidem, s. 35.
} 
tego dokonać w samotności. Wkrótce jednak, pod wpływem przykrych wydarzeń, jakie dotknęły poetę-emigranta, po raz kolejny zasadniczo zmienia on swój ton. Znalazłszy się na Krymie, mimo piękna i niespotykanego ogromu przyrody, on wyczekuje sygnału od swoich przyjaciół pozostawionych w ojczyźnie: „W takiej ciszy! - tak ucho natężam ciekawie, / Że słyszałbym głos z Litwy. - Jedźmy, nikt nie woła!"6.

W innym wierszu z cyklu Sonetów krymskich, Burza, znajdziemy inny obraz. Na statku, który w czasie sztormu znalazł się na morzu, panuje atmosfera pełna lęku. Ludzie modlą się, żegnają się z sobą pewni śmierci. Ale nie wszystkich ogarnęła taka atmosfera: „Jeden podróżny siedział w milczeniu na stronie / I pomyślił: szczęśliwy, kto siły postrada, / Albo modlić się umie, lub ma z kim się żegnać"7.

Te dwa obrazy - wędrowca wyczekującego w dalekim kraju na wiadomość z ojczyzny i podróżnego na statku, który w obliczu groźby śmierci nie potrafi się modlić, ani nawet nie ma towarzysza, z którym mógłby się pożegnać - należą do najbardziej dojmujących obrazów samotności w polskiej poezji romantycznej. Co ważne, obie postaci czują się osamotnione mimo tego, że znajdują się w gronie innych osób, innych podróżnych, z którymi jednak nie łączy ich absolutnie nic. Wytworzony w ten sposób kontrast tylko uwydatnia samotność obu postaci.

Wydaje się, że osobiste doświadczenia poety, jak i to, co działo się wówczas z całym narodem polskim, miało przemożny wpływ na światopogląd Mickiewicza. Kolejne utwory - to odwrót od indywidualizmu i uznanie konieczności związku ze „wspólnotą ludzką”. W roku 1828 w Rosji ukazał się poemat Mickiewicza Konrad Wallenrod. Jego główny bohater, rycerz z zakonu krzyżackiego, a w rzeczywistości Litwin, musi dokonać wyboru między dążeniem do własnej wielkości a wiernością narodowi, z którego się wywodzi. Podobną walkę między takimi dwiema rozbieżnymi wartościami musi stoczyć inny Mickiewiczowski Konrad - Gustaw-Konrad z III części Dziadów. W wygłoszonej przez niego Improwizacji (nazwanej później „Wielką”) znaleźć można wiele wątków typowych dla europejskiego romantyzmu - Konrad mówi o swojej samotności („Samotność - cóż po ludziach, czym śpiewak dla ludzi?”"8), chce być równy Bogu, któremu rzuca wyzwanie, mówi o swojej mocy i sile, o tym, że potrafi wybawić swój naród. Ale ostatecznie ponosi klęskę. Bluźniąc Bogu mdleje, a o jego duszę toczą bój demony i aniołowie. Dopiero modlitwa Księdza Piotra ratuje Konrada9 .

6 Ibidem, s. 215.

Ibidem, s. 218.

8 A. Mickiewicz, Dziady, Kraków 2002, s. 122.

9 Taki przebieg Improwizacji jest szczególnie ciekawy w zestawieniu z treścią wcześniejszych ustępów III części Dziadów - w Prologu jeden z Duchów mówi: „Człowieku! gdybyś wiedział, jaka twoja władza! / Kiedy myśl w twojej głowie, jako iskra 
Miejsc w twórczości Mickiewicza naznaczonych dychotomią samotności i wspólnotowości, poczuciem osamotnienia, myślą o konieczności zerwania ze społeczeństwem, ale też wyrazami poczucia więzi ze wspólnotą ludzką czy narodowa, jest niezwykle dużo, a omówienie ich wszystkich daleko wykraczałoby poza ramy tego tekstu. Wydaje się jednak, że szczególne w tym kontekście miejsce w dorobku Mickiewicza zajmuje zbiór prelekcji, jakie poeta w latach 1841-44 wygłosił w Collége de France. Badacze twórczości Mickiewicza dopiero od niedawna w należyty sposób zajmują się tym zbiorem i dopiero od niedawna zdają się przywiązywać do niego większą uwagę.

Jednym z tematów powracających najczęściej w toku czterech serii wykładów, jest miejsce, jakie w dziejach państw i narodów zajmują jednostki wybitne. Zagadnieniem tym zajmowało się wówczas wielu pisarzy i myślicieli - by wspomnieć chociażby Hegla w Niemczech, Carlyle’a w Anglii czy R.W. Emersona w Stanach Zjednoczonych. Jednak w przypadku koncepcji Mickiewicza dają się zauważyć pewne cechy typowe tylko dla niego samego.

Na przestrzeni czterech kursów poświęconych literaturze słowiańskiej możemy obserwować dość zasadniczą zmianę stanowiska Mickiewicza i stopniowe zwiększanie autonomii wybitnej jednostki w obrębie narodu, a twierdzenia zawarte w końcowych częściach kursu czwartego niejednokrotnie przeczyć będą twierdzeniom z wykładów początkowych. $Z$ całą pewnością znaczącą rolę $w$ tym umiejscowieniu idei między indywidualizmem a związkiem ze społeczeństwem odgrywa swoista demokratyzacja pojęć bohaterstwa i geniuszu, do jakiej dochodzi w okresie romantyzmu. Janion i Żmigrodzka udowadniają że „romantyzm uczynił (...) z bohaterstwa wartość dostępną wszystkim i każde$\mathrm{mu}$, starł z niego znamię arystokratyzmu rodowego, uczynił wyznacznikiem arystokratyzmu ducha"10. Od tego momentu dużo trudniej jest przeprowadzić wyraźną granicę między tymi, którzy są lub mogą stać się bohaterami, a tymi, którzy nie mają i nie będą mieli takiej możliwości. A więc trudniej wyznaczyć granicę między jednostkami wybitnymi, bohaterami.

Sposób myślenia polskiego wieszcza w znacznym stopniu został ukształtowany przez sytuację polityczna, która nie pozwalała oderwać zagadnień dobra i wolności jednostki od pamięci o dobru i wolności

w chmurze, / Zabłyśnie niewidzialna, obłoki zgromadza, /I tworzy deszcz rodzajny lub gromy i burze; / Gdybyś wiedział, że ledwie jednę myśl rozniecisz, / Już czekają w milczeniu, jak gromu żywioły, / Tak czekają twej myśli - szatan i anioły: / Czy ty w piekło uderzysz, czy w niebo zaświecisz; / A ty jak obłok górny, ale błędny, pałasz / I sam nie wiesz, gdzie lecisz, sam nie wiesz, co zdziałasz. / Ludzie! Każdy z was mógłby, samotny, więziony, / Myślą i wiarą zwalać i podźwigać trony" (ibidem, s. 102).

10 M. Janion, M. Żmigrodzka, Romantyzm i historia, op. cit., s. 186. 
narodu. Stąd tak częste w polskim romantyzmie wiązanie tych dwóch kwestii z sobą - uznawanie, że jednostka może osiągnąć suwerenność tylko wtedy, gdy jej naród będzie niepodległy. Wspominane wcześniej badaczki stwierdzaja że „w historii romantyzmu polskiego dominuje zmienny, a przecież nieustanny proces przepływu inspiracji między jednostką a narodową wspólnotą. Naród pojmuje sam siebie i odnajduje swą drogę w działaniu bohaterów, warunkiem i miarą wielkości indywiduum jest jego związek z przeczuciami, marzeniami, dążeniami wspólnoty, z "myślą ludu”, ze świadomością i pamięcią narodu. „Ja” romantyczne jest zakotwiczone $\mathrm{w}$ historycznym istnieniu zbiorowości. Przepływ czasu egzystencjalnego łączy się w nim z upływem czasu historycznego"11.

Całkowite oderwanie jednostki od narodu, właściwie niewyobrażalne w polskim romantyzmie, mogłoby więc podważyć całą strukturę odpowiedzialności - bohatera, wielkiego człowieka, wieszcza - za naród, ale i narodu za tę wybitną jednostkę, która poświęca się dla jego dobra.

Nie bez znaczenia dla Mickiewicza jest zapewne także paradygmat obecny w romantyzmie przynajmniej od czasów Byrona, choć zauważany już i wcześniej, a mianowicie napięcie istniejące na linii grupa-artysta. Wczesny romantyzm eksploatował ten problem bardzo intensywnie, co nie znaczy, że kolejne jego realizacje $w$ momencie wygłaszania omawianych tu wykładów nie pojawiały się. Bardzo często padało pytanie o utrzymanie się $\mathrm{w}$ ramach narzucanych przez społeczeństwo wzorców zachowania lub zerwanie z nimi i dążenie do prawdziwości, swobody i wolności twórczej. Jak pisze Ryszard Legutko w Traktacie o wolności, „artysta (...) dochodzić miał do swojej wolności w dwóch etapach. Najpierw zrywał z koniecznościami społeczeństwa, w jakich przyszło mu żyć, najczęściej kontestując jego obyczaje i odmawiając uczestnictwa w narzuconym systemie, a następnie oddawał się wolnej kreacji"12. Nie jest to zresztą problem typowy dla samego tylko romantyzmu. Nieco zaskakujący przykład z epoki wcześniejszej przytacza w Korzeniach romantyzmu Izajasz Berlin. Zaskakujący - bo autorstwa Diderota, encyklopedysty i arcyracjonalisty. Okazuje się, że ten francuski pisarz także zauważał problem rozpięcia jednostki wybitnej między własną swoboda, wolnością i niezależnością a społeczeństwem i cywilizacją. Uleganie ich wymogom może okazać się czymś niewłaściwym i po prostu nieszczerym - bo Diderot uznaje, że w każdym artyście, w każdym geniuszu jest coś, co umożliwia mu tworzenie wybitnych dzieł sztuki, a co nie ma nic wspólnego z cywilizacją czy społeczeństwem właśnie. Choć jednocześnie nie potrafi tego nazwać. W tekście Salon de 1765 Diderot ostrzega: „Strzeżcie się tych, których kieszenie pełne są esprit - dowcipu - i którzy

11 Ibidem, s. 24.

12 R. Legutko, Traktat o wolności, Gdańsk 2007, s. 96. 
wszędzie, przy każdej okazji tym dowcipem szafują. Nie mają oni w sobie demona, nie są posępni ani ponurzy, ani melancholijni, ani milczący. Nie bywają nigdy ani niezdarni, ani głupi. Skowronek, zięba, makolągwa, kanarek - wszystkie one ćwierkają i świergoczą przez cały boży dzień, a o zmroku chowają łebek pod skrzydło i oto już śpią. To właśnie wtedy geniusz zapala swoją lampę. I oto z gardła tego mrocznego, samotnego, dzikiego ptaka, tego nieujarzmionego stworzenia o ciemnych piórach wydobywa się śpiew, którym rozbrzmiewaja gaje, który mąci ciszę i który przełamuje mrok nocy"13.

Mamy więc w problemie stosunku wybitnej jednostki do społeczeństwa zawartych kilka elementów, wśród których najważniejsze to: problem rozwijającego się w ówczesnej filozofii podejścia indywidualistycznego i narastającą świadomość niemożliwości pogodzenia pełnej realizacji potrzeb jednostki z jednoczesną troską o państwo (czy też grupę narodową, etniczna, społeczną itp.) oraz obecny we wcześniejszej refleksji estetycznej i literackiej problem stosunku artysty-geniusza do społeczeństwa i obowiązujących w nim norm.

Adam Mickiewicz przywiązuje bardzo dużą wagę do związku wybitnej jednostki ze społeczeństwem, z którego się ona wywodzi oraz do sposobu, w jaki związek ten utrzymuje się, pomimo wyraźnych różnic ujawniających się w stosunkach między jednostką wybitną a społeczeństwem. Z jednej strony wielki człowiek wybija się ponad przeciętność społeczeństwa, nie należy do tłumu, do masy, "ludu" i dlatego może mu przewodzić, może być umieszczony gdzieś pomiędzy owym narodem, społeczeństwem czy grupą społeczną a wyższymi siłami i potęgami niematerialnymi $-\mathrm{z}$ drugiej zaś strony pochodzenie bohatera nie zostaje pominięte. Zdaniem polskiego poety przynależność narodowa jest jednym z najważniejszych przymiotów wielkiego człowieka. Dotyczy to nie tylko wielkich postaci z historii Polski - tak samo było z Mahometem i Arabami, podobnie jest z Napoleonem i Francuzami. Człowiek wielki jest takim, gdy „my wszyscy, którzy jesteśmy małymi, rozpoznajemy cząstkę siebie w jego wielkości"14. A więc wielki człowiek posiada pewne cechy - a może cechę - wspólne wszystkim ludziom, z którymi jest związany. Dzięki temu bohater potrafi odpowiadać na potrzeby swojego ludu, narodu - podzielając te same "porywy duszy" czy tę samą „istotę geniuszu” bohater wie dokładnie, co jest potrzebne danej społeczności, w jaki sposób może pomóc jej w drodze do doskonałości. Tej niezwykłej więzi z ludźmi sobie powierzonymi nie można rozerwać. Doświadczali tego prorocy starohebrajscy, którzy wciąż musieli zmagać

13 D. Diderot, Salon de 1765, red. Else Marie Bukdahl, Annette Lorenceau, Paris 1984, s. 47 ; cyt. za : I. Berlin, Korzenie romantyzmu, op. cit., s. 88.

14 A. Mickiewicz, Literatura słowiańska, przeł. L. Płoszewski, oprac. Julian Maślanka, Wydanie Rocznicowe, Warszawa 1998, tom X, s. 315. 
się z ludem skłonnym do częstego odchodzenia od prawa ustalonego przez Boga ${ }^{15}$. Zdaniem Mickiewicza Polska znalazła się właśnie w takim momencie dziejowym, w którym najwyraźniej odczuwa potrzebę znalezienia takiego człowieka, w którym byłoby możliwe skupienie jej sił, który zaczerpnąłby jakąś cząstkę od każdego Polaka - „Polacy (...) odczuli potrzebę jednego męża, który by był ich przedstawicielem"16. Wzorem dla Polaków mogą się tu okazać, co może zaskakujące, Rosjanie, którzy potrafią skupić całą energię narodu na jednej dynastii, na swoim władcy, któremu powierzają swój los. Mickiewicz dostrzega jednak niebezpieczeństwa, jakie takie postępowanie niesie z sobą - panowanie Piotra Wielkiego w Rosji, które miało być błogosławieństwem dla całego narodu, okazało się jego niewolą ${ }^{17}$.

Elementem wiążącym wielkiego człowieka nie musi być w tym wypadku naród - wystarczy określona grupa społeczna, której wielki człowiek stanie się wyrazicielem i którą będzie reprezentował. Tak postrzega Mickiewicz Mikołaja Reja: „wyrażał doskonale swój kraj i swą epokę, a zwłaszcza stan, do którego należał. Posiadamy żywot Mikołaja Reja, napisany przez jednego z jego przyjaciół, jednego ze współczesnych. Jest to zarazem życiorys wszystkich szlachciców polskich XVI wieku, życiorys warstwy najbardziej oświeconej"18.

Podobnie grupa społeczna oddziałała na Jana Długosza - pierwszego wielkiego, wybitnego kronikarza polskiego, przez którego kroniki przebija jego urodzenie i sprawowane stanowisko - ,jest on przede wszystkim duchownym i kapłanem. Przy roztrząsaniu każdego czynu stara się najpierw ocenić jego wartość moralną"19.

Taki jest punkt wyjścia każdego wielkiego człowieka - równość z innymi przedstawicielami swojego narodu, swojej klasy społecznej, z którą dzieli się emocje, biografię i wartości. Jest to jednak tylko jedna z faz rozwoju, która zdaniem Mickiewicza prowadzi do przekroczenia ograniczeń związanych z działalnością narodową. Uczestnictwo w zbawieniu rodaków jest konieczne, by przejść do następnej fazy - „do powszechności"20. Jednostka, której udało się wyzwolić z ram swojego narodu - jest Napoleon, którego za wielkiego uznają nie tylko jego rodacy, Francuzi, gdyż „Napoleon wywarł niezmierny wpływ duchowy na kraje słowiańskie, znacznie większy od wpływu wynikającego z jego działań wojennych i politycznych"21. Znajdujący się w tej fazie rozwo-

15 Ibidem, t. X, s. 161.

6 Ibidem, t. X, s. 15.

17 Ibidem, t. VIII, s. 25.

18 Ibidem, t. VIII, s. 469.

9 Ibidem, t. VIII, s. 367.

20 Ibidem, t. IX, s. 417.

${ }^{21}$ Ibidem, t. IX, s. 286. 
ju człowiek stoi już dużo wyżej od swoich rodaków. Nie jest już tylko przedstawicielem danego narodu, grupy społecznej, klasy - ale wciąż jest z nią związany. Mickiewicz powiada, że "duch najbardziej rozwinięty ma z natury rzeczy obowiązek prowadzić duchy znajdujące się na stopniach niższych"22. Jego misją wciąż pozostanie prowadzenie narodu na drodze do przyszłości, uczestnictwo w jego rozwoju, w jego „podnoszeniu sięe" 23 . Nie następuje więc u Mickiewicza całkowite oderwanie wielkiego człowieka od grupy, indywiduum nie jest pozostawione same sobie, bez zobowiązań, w przestrzeni zupełnej wolności i swobody ${ }^{24}$. Dzieje się tak nawet $\mathrm{w}$ momencie najintensywniejszego skierowania uwagi poety-profesora na jednostkę $e^{25} \mathrm{i}$ na jej udział w spełnianiu wolności, w dzianiu się historii.

Romantyzm jest epoką w rozwoju kultury europejskiej uznawaną bardzo często za źródło takich form wielu problemów, idei i koncepcji, jakie dotrwały do czasów nam współczesnych. W epoce tej bodaj po raz pierwszy na tak szeroką skalę podjęto namysł nad wartościami takimi, jak indywidualizm i kolektywizm, samodzielność i wspólnotowość, co nie znaczy - rzecz jasna - że kwestie te we wcześniejszej refleksji były nieobecne. $\mathrm{W}$ romantyzmie jednym $\mathrm{z}$ najważniejszych - być może najważniejszym - nośnikiem idei, była literatura, która przejmowała rolę wielu innych sposobów wyrazu i obszarów działalności ludzkiej (w tym filozofii). Refleksja nad samotnością, indywidualizmem i wspólnotowością mogła przybierać bardzo różne postaci i mogła być wyrażana za pomocą rozmaitych gatunków literackich. Bardzo niewielu twórcom udało się jednak znaleźć jedno słuszne - stałe i niezmienne - rozwiązanie tej kwestii. Mickiewicz nie należał do tego grona, a do tematu jednostkowości i wspólnotowości powracał od początków swojej poetyckiej kariery, do ostatnich tekstów, których był autorem. Jego twórczość, której ostatnim akordem były socjalizujące teksty pisane do „Trybuny Ludów”, udowadnia słuszność Berlinowskich enumeracji - rzeczywiście romantyzm to samotność, cierpienia związane z wygnaniem, błądzenie po odległych krainach - ale także dająca poczucie szczęścia współpraca we

22 Ibidem, t. X, s. 18.

23 Zob. ibidem, t. X, s. 20.

24 Michał Kuziak uważa, że rozwinięty indywidualizm Mickiewicz uznawał za chorobę tamtego czasu, a istnienie w obrębie wspólnoty narodowej miało być najlepszym na tę chorobę lekarstwem. Zob. M. Kuziak, Wielka całość. Dyskursy kulturowe Mickiewicza, Słupsk 2006, s. 248.

25 Marta Skwara w następujący sposób określa ewolucję, jaka dokonała się w rozumieniu mesjanizmu przez Mickiewicza w toku dwóch ostatnich kursów literatury słowiańskiej: punktem wyjścia jest mesjanizm plemienny, przechodzący w trakcie kursu III w mesjanizm Polski, który w kursie IV przeistacza się w mesjanizm osobowy (zob. M. Skwara, Mickiewicz i Emerson - prelekcje paryskie, „Pamiętnik Literacki” 1994, z. 3, s. 108). 
wspólnym twórczym wysiłku, organiczne więzi społeczne, mistyczna jedność, jedna wiara, jeden kraj, jedna krew.

\section{Streszczenie}

\section{"Nie ze mną trzeba być, lecz we mnie..." Problem samotności, indywidualizmu i wspólnoty w twórczości Adama Mickiewicza}

\section{Słowa kluczowe}

Indywidualizm; samotność; kolektywizm; romantyzm; Adam Mickiewicz; Isaiah Berlin

Romantyzm jest tą epoką w rozwoju kultury europejskiej, która bardzo często uznawana jest za moment narodzin formy wielu problemów, idei i koncepcji, która dotrwała do czasów nam współczesnych. Bez wątpienia jednym z najważniejszych mediów i być może najważniejszym nośnikiem idei, była w dobie romantyzmu literatura, która przejmowała rolę wielu innych sposobów wyrazu i obszarów działalności ludzkiej (w tym filozofii). Problem samotności i wspólnotowości był natomiast jednym z najczęściej eksplorowanych przez twórców romantycznych tematów.

Poeci i pisarze XIX-wieczni postrzegali te dwa pojęcia jako przeciwieństwa, a napięcie między jednostką a wspólnota, między samotnością a zaangażowaniem społecznym, obecne było w literaturze romantycznej już u jej źródeł. Problem ten przybierał różne postaci - zgubnego wpływu społeczeństwa na jednostkę, fascynacji postaciami wyjątkowymi, koniecznej (?) samotności geniusza, aż po dojrzała postać refleksji nad miejscem człowieka - także człowieka wybitnego - w społeczeństwie i wpływem wspólnoty na indywidualność. Szczególnie ciekawą postacią na tym tle okazuje się Adam Mickiewicz, który w całej swojej twórczości wciąż na nowo zmagał się z próbą rozstrzygnięcia swojego i każdej jednostki - miejsca i stosunku do społeczeństwa, wybrania bardziej właściwej drogi postępowania - rezygnacji ze związków ze wspólnotą ludzka, lub zupełnego zaangażowania na rzecz jej dobra. 


\section{Summary}

\section{"You need to be within me, not with me..." The problem of solitude, individualism and community in the works of Adam Mickiewicz}

\section{Key words}

individualism, solitude, collectivism, romanticism, Adam Mickiewicz, Isaiah Berlin

Romanticism is an era in European culture that is often seen as a birthplace of the form of numerous concepts and ideas that is present in the modern times. Undoubtedly one of the most important medium, maybe the most important carrier of ideas, was literature that took over many other forms and fields of human activity (including philosophy). The issue of solitude and community was one of the most interesting ones for numerous Romantic writers.

Poets and writers of the $19^{\text {th }}$ Century saw those two concepts as contradictions. The subject of tension between and individual and a community, between solitude and social commitment, was present at the roots of Romantic literature. This issue existed in different forms - as the subject of destructive influence of society on an individual, fascination with extraordinary individuals, the necessity (?) of genius' solitude, ending with a mature reflection on the place of a man (also an outstanding one) in society and society's influence on individuality. In this context, one particularly interesting writer, is Adam Mickiewicz, who in all his works returned to the problem of his (and every man's) place and relation to the society, of choosing the most appropriate conduct: declining all the relationships with human community, or complete engagement for the sake of it's well-being.

\section{Bibliografia}

Berlin I., Korzenie romantyzmu. Wykłady mellonowskie w zakresie sztuk pięknych wygłoszone w Narodowej Galerii Sztuki w Waszyngtonie, red. H. Hardy, tłum. A. Bartkowicz, Poznań 2004.

Diderot D., Salon de 1765, red. Else Marie Bukdahl, Annette Lorenceau, Paris 1984.

Janion M., Żmigrodzka M., Romantyzm i historia, Warszawa 1978.

Kuziak M., Wielka całość. Dyskursy kulturowe Mickiewicza, Słupsk 2006.

Legutko R., Traktat o wolności, Gdańsk 2007.

Mickiewicz A., Dziady, Kraków 2002.

Mickiewicz A., Literatura słowiańska, przeł. L. Płoszewski, oprac. J. Maślanka, Wydanie Rocznicowe, Warszawa 1998, t. VIII-XI.

Mickiewicz A., Wiersze, Warszawa 1986.

Skwara M., Mickiewicz i Emerson - prelekcje paryskie, "Pamiętnik Literacki” 1994, z. 3. 